\title{
Proteome oxidative carbonylation during oxidative stress-induced premature senescence of WI-38 human fibroblasts
}

Marine Le Boulch ${ }^{\mathrm{a} 1}$, Emad K. Ahmed ${ }^{\mathrm{b} 1}$, Adelina Rogowska-Wrzesinska ${ }^{\mathrm{c}}$, Martín A. Baraibar $^{\mathrm{d}}$ and Bertrand Friguet ${ }^{\mathrm{a} 2}$

aSorbonne Universités, UPMC Univ Paris 06, UMR 8256, Biological adaptation and ageing IBPS, CNRS UMR 8256, INSERM U1164, F-75005 Paris, France; biochemistry Department, Faculty of Science, Ain Shams University, Cairo, Egypt; 'Department of Biochemistry and Molecular Biology, University of Southern Denmark, Odense, Denmark; ${ }^{\mathrm{d} O x i P r o t e o m i c s ~ S A S, ~ F-75005 ~ P a r i s, ~ F r a n c e . ~}$

${ }^{1}$ Joint first authors

${ }^{2}$ Corresponding author

\section{CONTACT}

Prof. Bertrand Friguet (corresponding author).

e-mail: bertrand.friguet@upmc.fr

Tel.: +33(0)144273702

Fax: +33 (0)1 44275140

\section{RUNNING TITLE}

Protein oxidative carbonylation and SIPS 


\begin{abstract}
Accumulation of oxidatively damaged proteins is a hallmark of cellular and organismal ageing, and is also a phenotypic feature shared by both replicative senescence and stressinduced premature senescence of human fibroblasts. Moreover, proteins that are building up as oxidized (i.e. the "Oxi-proteome") during ageing and age-related diseases represent a restricted set of cellular proteins, indicating that certain proteins are more prone to oxidative carbonylation and subsequent intracellular accumulation. The occurrence of specific carbonylated proteins upon oxidative stress induced premature senescence of WI-38 human fibroblasts and their follow-up identification have been addressed in this study. Indeed, it was expected that the identification of these proteins would give insights into the mechanisms by which oxidatively damaged proteins could affect cellular function. Among these proteins, some are belonging to the cytoskeleton while others are mainly involved in protein quality control and/or biosynthesis as well as in redox and energy metabolism, the impairment of which has been previously associated with cellular ageing. Interestingly, the majority of these carbonylated proteins were found to belong to functional interaction networks pointing to signalling pathways that have been implicated in the oxidative stress response and subsequent premature senescence.
\end{abstract}

\title{
KEY WORDS
}

Protein oxidation; stress-induced premature senescence (SIPS); fibroblasts; oxidative stress; proteomics; ageing. 


\title{
HIGHLIGHTS
}

$>$ Oxidative carbonylation proteomics have been performed in fibroblasts after SIPS

$>$ A restricted set of increasingly carbonylated proteins have been identified

$>$ Several proteins belonging to the cytoskeleton have been found

$>$ Other proteins are involved in protein maintenance and intermediate metabolism

$>$ Data mining reveals potentially affected stress response-related signalling pathways

\begin{abstract}
ABBREVIATIONS
SIPS: stress-induced premature senescence; HDFs: human diploid fibroblasts; SIPS fibroblasts: stress-induced premature senescent fibroblasts; t-BHP: tert-butyl hydroperoxide; ROS: reactive oxygen species; IEF: isoelectrofocusing; DTT: dithiothreitol; RMI: relative modification index; MS: mass spectrometry; PBS: phosphate buffered saline; DNPH: dinitrophenylhydrazine; BSA: bovine serum albumin.
\end{abstract}




\section{INTRODUCTION}

Premature senescence can be induced in proliferating cells under conditions of increased oxidative stress (Toussaint et al., 2002a). Several experimental conditions have been used such as exposure of human diploid fibroblasts (HDFs) to subcytotoxic doses of stressing agents: hydrogen peroxide, tert-butyl hydroperoxide (t-BHP), ethanol, UV irradiation, strong electromagnetic fields, hyperoxia, etc... (Toussaint et al., 2000a). Within few days after exposure to the subcytotoxic stressor, HDFs become post-mitotic, display a typical senescent morphology and express several biomarkers of replicative senescence (Dumont et al., 2000). Hence, this senescent state occurring after subcytotoxic stresses was named stress-induced premature senescence (SIPS) (Toussaint et al., 2000b). Since the cell cycle is irreversibly arrested in stress-induced senescent cells, even if they are stimulated by various growth factors, it is thought that SIPS results in a cellular impairment that prevents cells from replicating. The recent demonstration that senescent cells are found in aged tissues and are important contributors to the ageing process in vivo and the development of age-associated pathologies, has led to an increased interest in those alternative senescence pathways that were previously evidenced only in vitro (Baker et al., 2011; Campisi and Robert, 2014; Adnot et al., 2015). Cells undergoing replicative senescence and those undergoing SIPS share common features but these two pathways for reaching senescence are different mostly because of the time at which these features are expressed. In replicative senescence, it has been proposed that the pathway is programmed and switched on when telomere attrition reaches a critical point, while for SIPS this is rather a response to a given stress. However, SIPS and replicative senescence are common in that the DNA damage response machineries are activated, either due to damage at non-telomere specific sites as signal in SIPS or at specific telomere ends as activating signal in replicative senescence. Using both transcriptomic and proteomic approaches, it was shown that SIPS and replicative senescence 
exhibit distinct gene and protein expression levels, even if they share similar phenotypic features (Dierick et al., 2000; Dierick et al., 2002).

Among the phenotypic features shared by both SIPS and replicative senescence of HDFs is the accumulation of oxidatively damaged proteins (Debacq-Chainiaux et al., 2005; Chondrogianni et al., 2003), which also represents a hallmark of cellular and organismal ageing (Levine and Stadtman, 2001; Nystrom, 2005). Furthermore, it has been proposed that the accumulation of damaged proteins during ageing is due to the dysregulation of both redox and protein homeostasis, resulting from an increased production of reactive oxygen species (ROS) and a decreased efficacy of cellular protein maintenance systems, such as the proteasome, that are responsible for their removal or repair (Friguet, 2006; Baraibar and Friguet, 2012; Chondrogianni et al., 2014). Oxidative damage to the cellular proteome, leading to the formation of carbonylated proteins derives from the direct oxidation of several amino acids side chains and also through protein adducts formation with lipid peroxidation products and dicarbonyl glycating compounds. Protein oxidative carbonylation is one of the most prominent protein damage since it is irreversible and it is related to a loss of function or a gain of toxic function of the targeted proteins (Grune et al., 2004; Stadtman, 2006; Nowotny et al., 2014). In addition, targeting of cellular proteins by carbonylation in ageing, cellular senescence and oxidative stress appears to be a rather selective process and recent studies have evidenced that the "Oxi-proteome" (i.e. the proteins that are building up as carbonylated) during ageing and age-related diseases is restricted to specific cellular proteins (Baraibar et al., 2012; Baraibar and Friguet, 2013). Factors underlying such selectivity are not completely understood and the relative abundance of proteins does not seem to be a necessary condition for a protein to be carbonylated. These factors have been proposed to rather include the presence of a transition metal-binding site that allow metal-catalysed oxidation, the abundance of amino acids susceptible to metal-catalysed oxidation, the rate of protein 
turnover, the protein conformation and its location in the proximity of ROS and other toxic compounds generation sites. As previously described for human fibroblasts and myoblasts undergoing replicative senescence (Ahmed et al., 2010; Baraibar et al., 2016), the identification of the "Oxi-proteome" of fibroblasts undergoing stress-induced premature senescence is expected to give insights into the mechanisms by which these oxidatively damaged proteins could affect cellular function and may also help to understand why these damaged proteins are building up in these prematurely senescent cells. In this study, we have investigated the occurrence of carbonylated proteins upon premature senescence of WI-38 fibroblasts 2 hours after oxidative stress and after a 30 days recovery period and we have identified in both cases proteins that belongs to the cytoskeleton and proteins that are mainly involved in protein quality control and/or biosynthesis as well as in redox and energy metabolism, the impairment of which has been previously associated with cellular ageing. Interestingly, these carbonylated proteins belongs to functional interaction networks pointing to signalling pathways as TGF- $\beta 1$, NTRK1, NFкB, Pkc, P38 MAPK, Akt, AMPK and ERK that are known to play a role either in the oxidative stress response and/or in premature cellular senescence (Toussaint et al., 2002b; Bernard et al., 2004; Maruyama et al., 2009; Salminen et al., 2012; Boilan et al., 2013).

\section{MATERIAL AND METHODS}

\subsection{WI-38 culture conditions and exposure to oxidative stress}

Human embryonic fibroblasts WI-38 were grown in Dulbecco's minimal essential medium (1 $\mathrm{g} / \mathrm{L}$ glucose) supplemented with $10 \%$ foetal calf serum, $100 \mathrm{U} / \mathrm{ml}$ penicillin, $100 \mu \mathrm{g} / \mathrm{ml}$ streptomycin and $2 \mathrm{mM}$ L-glutamine. Cultures were kept in an incubator at $37{ }^{\circ} \mathrm{C}$ and $5 \%$ $\mathrm{CO}_{2}$-containing atmosphere. Subconfluent cultures were obtained by seeding $5 \times 10^{5}$ cells/75 $\mathrm{cm}^{2}$ culture flasks and early passages (Cumulative population doublings $<25$ ) WI-38 cultures 
were used for exposure to oxidative stress. Cells were exposed to increasing amount of $\mathrm{H}_{2} \mathrm{O}_{2}$ for 2 hours at $37^{\circ} \mathrm{C}$ in a serum free media, then the cells were washed and given fresh culture medium. The sublethal dose of $\mathrm{H}_{2} \mathrm{O}_{2}$ was assessed by counting the number of total and nonviable cells using Trypan blue staining after a 24 hours recovery period. For the induction of SIPS the $\mathrm{H}_{2} \mathrm{O}_{2}$ concentration was set at the sublethal concentration of $500 \mu \mathrm{M}$ and the 2 hours exposure to $\mathrm{H}_{2} \mathrm{O}_{2}$ was repeated two times at one week interval.

\section{$2.2 \beta$-galactosidase staining}

Staining for $\beta$-galactosidase activity was performed as described by Dimri et al. (1995). Briefly, WI-38 cells were washed with PBS, fixed in $0.2 \%$ glutaraldehyde / $2 \%$ formaldehyde for 5 minutes at room temperature, and washed again with PBS. Cells were then stained at $37^{\circ} \mathrm{C}$ (in the absence of $\left.\mathrm{CO}_{2}\right)$ with fresh $\mathrm{SA}-\beta$-gal staining solution $(150 \mathrm{mM} \mathrm{NaCl}, 2 \mathrm{mM}$ $\mathrm{MgCl}_{2}, 5 \mathrm{mM}$ potassium ferricyanide, $5 \mathrm{mM}$ potassium ferrocyanide, and $40 \mathrm{mM}$ citric acid/sodium phosphate, $\mathrm{pH}$ 6.0) containing $1 \mathrm{mg} / \mathrm{ml}$ 5-bromo-4-chloro-3-indolyl- $\beta$-Dgalactoside. Staining was maximal after $15-20 \mathrm{~h}$ of incubation. 400 cells were counted each time and the number of positive cells was calculated as a percentage of the whole cells.

\subsection{Proteasome peptidase activities}

Peptidase activities of the proteasome were assayed with $20 \mu \mathrm{g}$ of protein lysate in $25 \mathrm{mM}$ Tris-HCl, $\mathrm{pH} 7.5$ at $37^{\circ} \mathrm{C}$ using fluorogenic peptides, Succinyl-Leu-Leu-Val-Tyraminomethylcoumarin at $12.5 \mu \mathrm{M}$ for the chymotrypsin-like activity and $\mathrm{N}$ benzyloxycarbonyl-Leu-Leu-Glu-naphthylamide at $150 \mu \mathrm{M}$ for the peptidylglutamyl-peptide hydrolase activity in a final volume of $200 \mu \mathrm{l}$ as previously described (Bulteau et al., 2000). Enzymatic kinetics were conducted in a temperature-controlled microplate fluorimetric reader (Fluostar Galaxy, bMG, Stuttgart, Germany). Proteasome activities were determined as the difference between total activity and the remaining activity of the crude lysate in the presence of $20 \mu \mathrm{M}$ of proteasome inhibitor N-Cbz-Leu-Leu-Leucinal (MG132). All measurements 
were repeated a minimum of three times and results are expressed as mean \pm standard deviation (SD). Data were analysed by two-way ANOVA followed by Bonferroni's post hoc test and significance was set at $\mathrm{P}<0.05$.

\subsection{Two-dimensional gel electrophoresis}

Sample preparation- WI-38 fibroblasts were washed once with PBS, scrapped into $5 \mathrm{ml}$ PBS, pelleted by centrifugation for $5 \mathrm{~min}$ at $1000 \mathrm{~g}$ and then kept at $-20{ }^{\circ} \mathrm{C}$ until analysis. Cell pellets were suspended in lysis buffer (2\% CHAPS, 0.1 M DTT in $50 \mathrm{mM}$ Tris-HCl, pH 7.4 and complete protease inhibitor cocktail). Cells were lysed by sonication for 4 x $5 \mathrm{sec}$ using a Branson Sonifier 150 followed by incubation with benzonase $(500 \mathrm{U} / \mathrm{ml})$ for $90 \mathrm{~min}$ at $4{ }^{\circ} \mathrm{C}$ with agitation. Cell lysates were obtained after centrifugation at $15000 \mathrm{~g}$ for $10 \mathrm{~min}$ at $4^{\circ} \mathrm{C}$ and protein concentration was determined by the method of Bradford (Bio-Rad protein assay, Marnes La Coquette, France).

Isoelectrofocusing (IEF) - Aliquots of $150-300 \mu \mathrm{g}$ of proteins were diluted in $250 \mu \mathrm{l}$ rehydration solution (7 M urea, $2 \mathrm{M}$ thiourea, $4 \%$ 3-[(3-cholamidopropyl) dimethylammonio]-1-propanesulfonate (CHAPS), $65 \mathrm{mM} \mathrm{DTT,} 2 \%$ IPG buffer (v/v). The protein samples were loaded into the IPG strips 3-10 NL $(13 \mathrm{~cm})$, by in gel rehydration at room temperature overnight. IEF was performed as previously described (Ahmed et al., 2010). After IEF, the IPG strips were stored at $-80{ }^{\circ} \mathrm{C}$ until used in the second dimension.

In-strip derivatisation of protein-bound carbonyls, SDS-PAGE and 2D-OxyBlot- After IEF the IPG strips 3-10 NL were incubated at room temperature in $10 \mathrm{ml}$ of $10 \mathrm{mM} \mathrm{DNPH} / 2 \mathrm{M}$ $\mathrm{HCl}$ for $20 \mathrm{~min}$ with agitation. Strips were neutralized with $2 \mathrm{M}$ Tris-base containing $30 \%$ glycerol for $10 \mathrm{~min}$ and this step is repeated one time for $30 \mathrm{~min}$. IPG strips were equilibrated for $15 \mathrm{~min}$ in $10 \mathrm{ml}$ equilibration buffer (6 M urea, 2\% SDS, 30\% glycerol, $1 \%$ DTT in 50 $\mathrm{mM}$ Tris- $\mathrm{HCl}, \mathrm{pH} 8.8$ ) and then for $15 \mathrm{~min}$ in equilibration buffer containing traces of bromophenol blue and 3\% iodoacetamide instead of DTT. The strips were placed on $12 \%$ 
polyacrylamide gels according to Laemmli (1970) and electrophoresis was carried out using the cooling Protean II system (BioRad, Marnes La Coquette, France). After 2D electrophoresis the proteins are blotted onto a nitrocellulose membrane for $3 \mathrm{~h}$ at a fixed voltage of $100 \mathrm{~V}$. The blots were then incubated for $2 \mathrm{~h}$ at room temperature in blocking buffer (PBS supplemented with 1\% BSA and 0.1\% Tween 20) and detection of carbonyl groups was performed with the OxyBlot ${ }^{\mathrm{TM}}$ oxidized protein detection kit according to the manufacturer's protocol.

\subsection{Protein staining and image analysis}

The 2D separated protein spots were visualized with colloidal blue staining and the stained gels and films were digitized with UMAX UTA-100 scanner (GE Healthcare, Saclay, France). The spot detection and quantification were done with the Image Master 2D Platinium 7 software (GE Healthcare, Saclay, France) and the data were expressed as spot \% volume in pixels.

\subsection{In-gel digestion, mass spectrometry and database searches}

Spots of interest were manually excised from gels and proteins were digested with trypsin as described previously (Ahmed et al., 2010). Peptide mass spectra were acquired in positive reflector mode on a 4800 Plus MALDI TOF/TOFTM Analyser (Applied Biosystems, Foster City, CA, USA) using $20 \mathrm{kV}$ of acceleration voltage. MS and MS/MS peak lists were combined into search files and used to search SwissProt databases using the Mascot search engine (Matrix Science Ltd, London, UK). Mascot protein scores greater than 56 are significant at $\mathrm{p}<0.05$.

\subsection{Metabolic Analyses.}

Intracellular metabolites profiling analysis was performed by Metabolon, Inc. as previously described (Reitman et al., 2011). Cellular pellets ( $10^{6}$ cells) from six different batches from 
control WI-38 fibroblasts and four different batches of SIPS WI-38 fibroblasts were prepared and accessioned into the Metabolon LIMS system.

Ultrahigh performance liquid chromatography/Mass Spectroscopy (UPLC/MS/MS). The LC/MS portion of the platform was based on a Waters ACQUITY ultra-performance liquid chromatography (UPLC) and a Thermo-Finnigan linear trap quadrupole (LTQ) mass spectrometer. Sample extracts were dried and then reconstituted in acidic or basic LCcompatible solvents, each of which contained 8 or more injection standards at fixed concentrations to ensure injection and chromatographic consistency.

Gas chromatography/Mass Spectroscopy (GC/MS). The samples destined for GC/MS analysis were re-dried under vacuum desiccation for a minimum of $24 \mathrm{~h}$ prior to being derivatised under dried nitrogen using bistrimethyl-silyl-triflouroacetamide (BSTFA). Samples were analysed on a Thermo-Finnigan Trace DSQ fast-scanning single-quadrupole mass spectrometer using electron impact ionization.

Data extraction and compound identification. Raw data was extracted, peak-identified and QC processed using Metabolon's hardware and software (DeHaven et al., 2010). Welch's two-sample $t$-test was used to identify biochemicals that differed significantly between experimental groups.

\subsection{Functional pathways analysis}

Functional pathway and network analyses were generated using the Ingenuity pathway analysis software (version 2.0, Ingenuity ${ }^{\mathrm{TM}}$ Systems, Mountain view, CA). Ingenuity pathway analysis identified those canonical pathways, biological processes and gene interactions networks that were most significant for the carbonylated proteins identified in WI-38 fibroblasts upon oxidative stress-induced premature senescence. Each protein designation was mapped in the Ingenuity Pathways Knowledge Base. 


\section{RESULTS}

\subsection{Determination of the subcytotoxic dose of $\mathrm{H}_{2} \mathrm{O}_{2}$ and induction of premature senescence of WI-38 human fibroblasts:}

WI-38 human fibroblasts were grown as described in Material and Methods until they have reached $80 \%$ confluence and they were exposed to increasing amount of $\mathrm{H}_{2} \mathrm{O}_{2}$ for 2 hours at $37^{\circ} \mathrm{C}$ in a serum-free media, then the cells were washed and given fresh culture medium. The subcytotoxic dose of $\mathrm{H}_{2} \mathrm{O}_{2}$ was assessed by counting the number of total and non-viable cells after a 24 hours recovery period. As shown in Figure 1A, cell mortality was evident at concentrations of $\mathrm{H}_{2} \mathrm{O}_{2}$ higher than $500 \mu \mathrm{M}$. Hence, for the induction of SIPS the $\mathrm{H}_{2} \mathrm{O}_{2}$ concentration was set at $500 \mu \mathrm{M}$ and the 2 hours exposure to $\mathrm{H}_{2} \mathrm{O}_{2}$ was repeated two times at one week interval. The occurrence of oxidized proteins was monitored in cellular protein lysates using the protein carbonyl Oxyblot ${ }^{\mathrm{TM}}$ assay as described in Material and Methods at different recovery periods after oxidative stresses. As shown in Figure 1B, the level of oxidized protein is increased during the first hours after stress and then comes back to basal for about one week before increasing again after two weeks. Since the proteasome is the main proteolytic system that has been implicated in the removal of oxidized proteins, proteasome peptidases activities were also measured in cellular protein extracts as described in Material and Methods at different recovery periods following oxidative stresses. Interestingly, both chymotrypsin-like and peptidyl-glutamylpeptide hydrolase activities were decreased during the first hours after stress and then came back to normal after one week and stayed around this level during the following three weeks (Figure 1C). Finally, the senescent status of the cell culture was evaluated qualitatively by the characteristic cellular enlargement and flattening of the fibroblasts (Figure 1D) and quantitatively by the count of the $\beta$-galactosidase positive cells and total cells (Figure 1E) as described in Material and Methods. At two hours after the oxidative stresses, around $80 \%$ of the cells were already positive for $\beta$-galactosidase activity 
and almost $100 \% \beta$-galactosidase positive senescent cells were found after a thirty days recovery period.

\subsection{Characterization of carbonylated proteins in WI-38 fibroblasts submitted to oxidative stresses and SIPS}

SIPS was induced in WI-38 fibroblasts upon their exposure for 2 hours to a $500 \mu \mathrm{M}$ concentration of $\mathrm{H}_{2} \mathrm{O}_{2}$ two times at one week interval. Cellular lysates were prepared from WI-38 fibroblasts that have not been treated with $\mathrm{H}_{2} \mathrm{O}_{2}$ (i. e. control fibroblasts) and from $\mathrm{H}_{2} \mathrm{O}_{2}$ twice treated WI-38 fibroblasts (i.e. SIPS fibroblasts) after a short recovery period of 2 hours and a long recovery period of 30 days, respectively. Proteins modified by carbonylation were analysed by a 2D gel-based proteomic approach as described in Material and Methods. Two gels were prepared in parallel for each sample, the first one for the visualization of total proteins after Coomassie colloidal blue staining and the subsequent identification by MS analysis and the second one for blotting against specific polyclonal anti-DNP antibodies to visualize the carbonylated proteins as described in Material and Methods. Such an experiment is presented in Figure 2 and the protein spots were quantified over gels and blots using the Image Master 2D software from GE Healthcare. Protein spots were quantified as \% volume $(\% \mathrm{~V})$ which is a normalized value that remains relatively independent of irrelevant variations between images. Because of possible variations in protein expression levels, for each spot a relative modification index (RMI) was calculated, which is the ratio of quantification value of protein spot on membrane to its corresponding value on gel. These RMI values were further normalized as $\mathrm{RMI}$ ratios $\left(\mathrm{RMI}_{\mathrm{SIPS}} / \mathrm{RMI}_{\text {Control }}\right)$. Several spots were found on the immunoblots which are increasingly carbonylated by at least $30 \%$ (RMI ratio $\geq 1.3$ ) in SIPS WI-38 fibroblasts after either a short recovery period of 2 hours (26 spots for SIPS $2 \mathrm{~h}$ ) and a long recovery period of 30 days (19 spots for SIPS d30) when compared with control ones, respectively (Figure 3). For most of these protein spots, their expression level variations were 
within 30\% increase or decrease, the highest increased and decreased expression levels being 1.8 fold for spot 1 and 2.2 fold for spot 21 , respectively.

\subsection{Identification of carbonylated proteins in WI-38 fibroblasts submitted to oxidative}

\section{stresses and SIPS}

The increasingly carbonylated protein spots were excised from their respective Coomassie colloidal blue stained gels, subjected to tryptic digestion and analysed by MALDI-TOF/TOFMS for protein identification as described in Material and Methods. All spots were successfully identified and the proteins listed on Tables 1 and 2 have been assigned a significant Mascot score. In either situation of short and long recovery periods, the 27 identified proteins were belonging to either the cytoskeleton or were proteins that are mainly involved in protein quality control and/or biosynthesis as well as in redox and energy metabolism, the impairment of which has been previously associated with cellular ageing. The subcellular location of the carbonylated proteins was mainly cytosolic ( 21 out of 27 which is almost $80 \%$ ) with few other proteins belonging to either plasma membrane (3 proteins out of 27), endoplasmic reticulum (2 proteins out of 27) and nucleus (1 protein out of 27). Interestingly, 6 proteins were found increasingly carbonylated for both situations of short or long recovery periods (Figure 4A). Since, among those modified proteins were represented glucose-6-phosphate dehydrogenase and enolase that are both involved in carbohydrate metabolism, the pentose phosphate and the glycolytic pathways respectively, as well as protein disulfide isomerase $\mathrm{A} 3$, a redox chaperone involved in the refolding of disulfide containing proteins, the level of several carbohydrates and redox metabolites were monitored two weeks after SIPS as described in Material and Methods. None of the assayed glycolytic and Krebs cycle intermediate metabolites in SIPS fibroblasts showed significant variation as compared with control fibroblasts but for isobar: ribulose 5-phosphate, xylulose 5-phosphate which was increased by 2.2 fold for pentose metabolism (Figure 4B) while the total level of 
NADP was decreased by 2.6 fold (Figure 4C) and the level of coenzyme A was decreased by 4 fold (Figure 4D). Among redox metabolites, both cysteine-gluthatione disulfide and methionine sulfoxide were increased by 1.6 and 2.6 fold, respectively (Figures 4E \& 4F) while no significant variation of reduced and oxidized glutathione was observed.

\subsection{Functional network integration of SIPS associated carbonylated proteins}

The carbonylated proteins identified in SIPS WI-38 fibroblasts after either a short recovery period of 2 hours (20 proteins for SIPS $2 \mathrm{~h}$ ) or a long recovery period of 30 days (13 proteins for SIPS d30) were analysed for network integration using the Ingenuity Pathway Analysis ${ }^{\mathrm{TM}}$ Software. Indeed, such information would be of interest to point out metabolic and/or signalling pathways that may be impacted by the loss of protein function and/or regulation that has been generally associated to protein oxidative carbonylation. The proteins identified for SIPS-2h were found to belong to two different networks (Figures 5A \& 5B), one being centered on NTRK1, a pro-survival kinase that has been implicated in MAP kinase kinase activity, and TGF- $\beta 1$ (Figure 5A), a secreted polypeptide member of the transforming growth factor beta superfamily of cytokines that performs many cellular functions, including the control of cell growth, cell proliferation, cell differentiation and apoptosis. Interestingly, TGF- $\beta 1$ has also been causally involved in the induction of SIPS upon $\mathrm{H}_{2} \mathrm{O}_{2}$ treatment and UVB irradiation of human fibroblasts (Frippiat et al., 2001; Debacq-Chainiaux et al., 2005). The second network obtained with increasingly carbonylated proteins for SIPS-2h was more complex (Figure 5B) and included such signalling proteins as NFkB, P38 MAPK, ERK, Akt, Pkc and AMPK. For the carbonylated proteins identified in SIPS WI-38 fibroblasts after a long recovery period of 30 days (13 proteins), only one network was obtained with Histone $\mathrm{H} 3$ and most of the signalling proteins reported above for the second network of increasingly carbonylated proteins for SIPS-2h: P38 MAPK, ERK, Pkc and AMPK (Figure 5C). 


\section{DISCUSSION}

In this study, we have investigated the occurrence of protein carbonylation in WI-38 fibroblasts upon SIPS, 2 hours following $\mathrm{H}_{2} \mathrm{O}_{2}$ induced oxidative stress and after a 30 days recovery period. In addition, we have successfully identified the "Oxi-proteome" (i.e. the restricted set of increasingly carbonylated proteins) of these fibroblasts undergoing stressinduced premature senescence. Indeed, increased protein oxidative damage has been clearly associated to both cellular and organismal ageing and accumulation of oxidatively damaged proteins has been also reported in HDFs upon both replicative and SIPS (Chondrogianni et al., 2003; Debacq-Chainiaux et al., 2005). We have previously identified proteins targeted by such modifications as carbonylation, conjugation by the lipid peroxidation product 4hydroxynonenal and formation of advanced glycated end-products in human fibroblasts and myoblasts upon replicative senescence (Ahmed et al., 2010; Baraibar et al., 2016). As for the current study, these studies were carried out using 2D gel-based proteomic approach combined with immunodetection of these oxidatively modified proteins since this methodology gives the possibility to globally analyse the pattern of modified proteins in cells and tissues (Møller et al., 2011; Rogowska-Wrzesinska et al., 2013). For protein carbonylation, highly sensitive fluorescent hydrazide probes have been set up since and were found to match the sensitivity of immunodetection of the protein carbonyldinitrophenylhydrazone derivatives. These probes represent powerful tools for the quantitative assessment of the "Oxi-proteome" within the complex mixture of proteins found in any protein containing biological sample (Tamarit et al., 2012; Baraibar et al., 2013; Rogowska-Wrzesinska et al., 2014).

Concerning fibroblasts and myoblasts undergoing replicative senescence, restricted sub-sets of oxidatively modified proteins were previously found with some overlapping proteins and some cell-type specific proteins, suggesting that these latter proteins may 
differently affect cellular function during replicative senescence. Among them were proteins belonging to the cytoskeleton, proteins involved in energy, carbohydrate and redox metabolism as well as proteins involved in protein maintenance (Ahmed et al., 2010; Baraibar et al., 2016). Interestingly, although the method used to prepare cell lysates and the protein extraction protocol were basically the same, an important number of modified mitochondrial proteins were found in senescent fibroblasts while most of the modified proteins found in senescent myoblasts were cytosolic. In this study, only carbonylated proteins were analysed in SIPS fibroblasts and they were mainly cytosolic and also either belonging to the cytoskeleton, involved in redox and energy metabolism or involved in protein maintenance (Tables $1 \& 2$ and Figure 4A). Interestingly, cytoskeleton, redox and energy metabolism as well as protein maintenance have been all reported to be impaired during cellular ageing. Such carbonylated proteins accumulating in SIPS that were already found for replicative senescence of both fibroblasts and myoblasts include: Vimentin, Glucose-6-phosphate dehydrogenase and Heat shock cognate $71 \mathrm{kDa}$ protein. Other carbonylated proteins that were previously identified in either myoblasts exposed to $\mathrm{H}_{2} \mathrm{O}_{2}$ induced oxidative stress or senescent myoblasts include: Enolase, Protein disulfide-isomerase A3, Glyceraldehyde-3-phosphate dehydrogenase, Pyruvate kinase, Heat shock cognate $71 \mathrm{kDa}$ protein, Glucose-6-phosphate dehydrogenase and Annexin A2. Finally, such proteins as Vimentin, Tubulin, Actin, Glyceraldehyde-3phosphate dehydrogenase, Enolase, Pyruvate kinase, Protein disulfide-isomerase, Catalase and Heat shock cognate $71 \mathrm{kDa}$ protein have also been identified as increasingly modified in different models of ageing and age-related diseases (Baraibar et al., 2012; Baraibar and Friguet, 2013).

A similarity in the proteins targeted by oxidation emerges, to a certain extent, from these comparisons and suggests that specific cellular functions might be affected by the buildup of this restricted set of oxidatively modified proteins due to their impaired functionality 
and/or altered regulation. This assumption is supported in SIPS fibroblasts by changes in the levels of such metabolites as ribulose 5-phosphate + xylulose 5-phosphate (Figure 4B). Both metabolites are part of the pentose-phosphate pathway which is providing intracellular reducing power through reduced NADPH production and is critically dependent on Glucose6-phosphate dehydrogenase integrity. In addition, the overall level of NADP, which is a cosubstrate of both Glucose-6-phosphate dehydrogenase and 6-phosphogluconate dehydrogenase was decreased in SIPS fibroblasts (Figure 4C), arguing for a decreased efficiency of the pentose-phosphate pathway. Since, NADP is mostly produced through the phosphorylation of NAD (Love et al., 2015), the decreased level of NADP may be related with previously reported alterations in $\mathrm{NAD}^{+}$metabolism in replicatively senescent human fibroblasts (James et al., 2016). However, no significant change was found in $\mathrm{NAD}^{+}$and NADH levels in SIPS fibroblasts while elevated levels of NADP were reported in replicatively senescent human fibroblasts (James et al., 2016). Another important metabolite for energy metabolism is Coenzyme A, the level of which was decreased by 4 fold in SIPS fibroblasts. This may results in a negative impact on both the transfer of fatty acids from the cytoplasm to the mitochondria for their $\beta$-oxidation and on the delivery of the acetyl group to the citric acid cycle to be oxidized for mitochondrial energy production.

Oxidatively modified proteins build-up that occurs during ageing and cellular senescence is believed to result, at least in part, from the increase of reactive oxygen species and other toxic compounds coming from both cellular metabolism and external factors. Experimental evidence has also indicated that failure of protein maintenance systems such as the proteasome, can also be a major contributor to the age-associated accumulation of damaged proteins (Chondrogianni et al., 2003; Petropoulos and Friguet, 2005; Baraibar and Friguet, 2012) that is believed to participate to the age-related decline in cellular function. Although the proteasome peptidase activities were transiently decreased after oxidative stress, 
they were almost restored in the senescent cells after one week up to four weeks recovery periods while a build-up of carbonylated proteins is still observed. These results are in line with those obtained upon UVB induced premature senescence of human fibroblasts and keratinocytes for which no proteasome inhibition was reported (Debacq-Chainiaux et al., 2005; Bertrand-Vallery et al., 2010). Hence, persistent redox dysregulation, as evidenced by an increase in such metabolites as methionine sulfoxide and cysteine-glutathione (Figure 4E \& 4F) which represents two compounds formed under oxidative stress conditions, is most likely implicated in the accumulation of carbonylated proteins for $\mathrm{H}_{2} \mathrm{O}_{2}$ induced premature senescence of WI-38 fibroblasts. Moreover, the increased load of carbonylated heat shock cognate $71 \mathrm{kDa}$ and heat shock protein $90 \mathrm{kDa} \beta$ chaperone proteins may also contribute to an impaired removal of damaged or abnormal proteins by chaperone-mediated autophagy (Cuervo and Wong, 2014) and by CHIP ubiquitin ligase mediated degradation by the proteasome (Murata et al., 2003; Sisoula and Gonos, 2011).

Finally, a network analysis using Ingenuity Pathways Analysis ${ }^{\mathrm{TM}}$ software was performed for carbonylated proteins that are accumulating in SIPS fibroblasts to obtain further insights into the cellular pathways that might be affected by protein carbonylation which is generally associated to a loss of protein function and/or a gain of toxic function. The 20 proteins identified for SIPS 2 h (i. e. 2 hours following $\mathrm{H}_{2} \mathrm{O}_{2}$ induced oxidative stress) were grouped in two different networks (Figures 5A \& 5B). The first network (Figure 5A) is based on 4 proteins that are no longer accumulating after the 30 days recovery period and is centered on NTRK1 (neurotrophic tyrosine receptor kinase 1) and TGF- $\beta 1$ (the transforming growth factor beta 1). NTRK1, also known as tropomyosin receptor kinase A, is a prosurvival kinase that has been implicated in the activation of downstream signalling cascades via PI3K, RAS/MAPK/ERK, and PLC- $\gamma$ that induces cell proliferation, differentiation, apoptosis, and survival of neurons and other cells types (Khotskaya et al., 2017). TGF- $\beta 1$ has 
been implicated in many cellular functions, including the control of cell growth, cell proliferation, cell differentiation, apoptosis and in particular in SIPS and ageing (Toussaint et al., 2002b). In particular, TGF- $\beta 1$ activation has been shown to drive the entrance of HDFs in premature senescence following oxidative stress (Frippiat et al., 2001; Debacq-Chainiaux et al., 2005). The second network is based on 16 proteins among which 6 of them are also accumulating after a 30 days recovery period. This network includes such signalling proteins as NFkB, P38 MAPK, ERK, Akt, Pkc and AMPK among which P38 MAPK, ERK, Pkc and AMPK are also part of the network obtained for the 13 carbonylated proteins identified in SIPS WI-38 fibroblasts after a long recovery period of 30 days (Figure 5C). Interestingly, all these signalling proteins have been previously implicated in the oxidative stress response and subsequent stress-induced premature senescence (Toussaint et al., 2002b; Bernard et al., 2004; Maruyama et al., 2009; Salminen et al., 2012; Boilan et al., 2013) which suggests that the "Oxi-proteome" might interfere with functional connections within these relevant signalling pathways. Interestingly, a decreased activation of the pro-survival Akt and ERK kinases has been previously reported for aged HDFs as compared to HDFs from young individuals upon exposure to hydrogen peroxide (Gurjula et al., 2005). Taken together, these results suggest that the cellular senescence-associated "Oxi-proteome" (i. e. the restricted set of cellular proteins that are building up as oxidized proteins) may not only contribute to the senescent phenotype by affecting certain metabolic pathways, such as those involved in energy and redox metabolism (Baraibar and Friguet, 2013; Baraibar et al. 2016), but may also participate to the establishment and maintenance of the senescent state by impacting on specific intracellular signalling pathways. Hence, improved removal of oxidized proteins and/or increased protection of the proteome against oxidation would be expected to help preventing cellular senescence and consequently slowing-down the pro-aging effects of senescent cells at the tissue and organ levels. 


\section{FIGURE LEGENDS}

\section{Figure 1: Characterization of SIPS WI-38 after $\mathrm{H}_{2} \mathrm{O}_{2}$ oxidative stresses.}

The sublethal dose of $\mathrm{H}_{2} \mathrm{O}_{2}$ was assessed in WI-38 fibroblasts by counting the number of nonviable and total cells $24 \mathrm{~h}$ after a $2 \mathrm{~h}$ incubation with different concentrations of $\mathrm{H}_{2} \mathrm{O}_{2}$ as described in Material and Methods (A). Protein total cellular lysates were prepared from $\mathrm{H}_{2} \mathrm{O}_{2}$ stressed cells harvested at different times after the stress and were submitted to the OxyBlot ${ }^{\mathrm{TM}}$ carbonylated protein detection assay for the determination of carbonylated proteins that were quantified using the Image $\mathrm{J}(\mathrm{NIH}$, Bethesda, USA) software (B) and for the measurements of the chymotrypsin-like (CT-L) and peptidylglutamylpeptide hydrolase (PGPH) peptidase activities of the proteasome (C) as described in Material and Methods. Senescent cells were monitored by staining for $\beta$-galactosidase activity (D \& E) as described in Material and Methods.

\section{Figure 2: 2D-Oxyblot analysis of SIPS WI-38 after $\mathrm{H}_{2} \mathrm{O}_{2}$ oxidative stresses.}

$150 \mu \mathrm{g}$ of total proteins of each cellular lysates (Control, SIPS $2 \mathrm{~h}$ and SIPS d30) were first separated on IPG strips $\mathrm{pH}$ 3-10 non-linear and derivatised by dinitrophenyl hydrazine (DNPH) as described in Material and Methods. IPG strips were then placed on top of a $12 \%$ PAGE and protein separation was achieved in denaturing conditions in the presence of SDS. After the second dimension, gels were either stained with colloidal Coomassie brilliant blue (right panels) or electro-transferred onto nitrocellulose membranes for subsequent immunodetection of carbonylated protein spots and their follow-up quantification and matching using Image Master 2D Platinium 7 software as described in Material and Methods (left panels). This experiment was performed in quadruplicate. 


\section{Figure 3: Coomassie blue staining of the 2D preparative gels.}

Numbers and positions of selected spots located in the master gels (fold change $\geq 1.3$ for increasingly carbonylated spots), for their identification by MALDI-TOF/TOF-MS as described in Material and Methods.

\section{Figure 4: Carbonylated proteins and measurement of selected metabolites in SIPS WI-}

\section{8 fibroblasts.}

Venn diagram (A) depicting the distribution of proteins increasingly carbonylated proteins in SIPS WI-38 fibroblasts after a short recovery period of 2 hours (SIPS $2 \mathrm{~h}$ ) and a long recovery period of 30 days (SIPS d30). Altered metabolites in SIPS fibroblasts (FIS) versus control young fibroblasts (FY) were monitored as described in Material and Methods and are related to the pentose phosphate pathway (B and C), to mitochondria based energy metabolism (D) and to oxidative stress conditions (E and F).

\section{Figure 5: Cellular pathway analysis.}

Networks were obtained using Ingenuity Pathway for carbonylated proteins in SIPS WI-38 fibroblasts after a short recovery period of 2 hours (SIPS $2 \mathrm{~h} /$ networks A and B) and a long recovery period of 30 days (SIPS d30 / network C). Proteins in red correspond to some of the proteins identified by MALDI-TOF/TOF-MS after Oxyblot ${ }^{\mathrm{TM}}$. Proteins in green were not identified as carbonylated in this analysis but they represent central nodes associated with the regulation of some of the proteins identified. Information about the analysis of biological functions and pathways as well as network interactions is available at the Ingenuity pathway analysis website. A line denotes binding of proteins, whereas a line with an arrow denotes “acts on". A dotted line denotes an indirect interaction 


\section{FOOTNOTES TO TABLES}

Table 1: Carbonylated proteins in stress-induced premature senescent WI-38 fibroblasts (SIPS 2h). Spots of interest were identified by MS as described in Material and Methods. Protein spot no (a) refer to numbered spots on Figure 3. For each spot, different parameters clarifying protein identification by MS are indicated [(accession number (b), Ingenuity Pathway Analysis symbol (c) mass (d), mascot score (e), \% sequence coverage (f)]. (g) RMI ratio represents the Relative Modification Index Ratio and (h) means that the modified protein was only detected in SIPS $2 \mathrm{~h}$ samples.

Table 2: Carbonylated proteins in stress-induced premature senescent WI-38 fibroblasts (SIPS d30). Spots of interest were identified by MS as described in Material and Methods. Protein spot no (a) refer to numbered spots on Figure 3. For each spot, different parameters clarifying protein identification by MS are indicated [(accession number (b), Ingenuity Pathway Analysis symbol (c) mass (d), mascot score (e), \% sequence coverage (f)]. (g) RMI ratio represents the Relative Modification Index Ratio and (h) means that the modified protein was only detected in SIPS d30 samples. 


\section{ACKNOWLEDGMENTS}

This paper is part of a special issue of Mechanisms of Ageing and Development on "Stress and senescence" dedicated to the memory of Dr Olivier Toussaint, University of Namur, Belgium. EKA was recipient of a fellowship from the Egyptian Ministry of Research and is currently lecturer at the Ain Shams University, Department of Biochemistry, Cairo, Egypt. MLB was appointed as technical associate in the EU Proteomage project and is currently project manager at Eukaÿs, Paris, France. The authors thank Mrs Marie-Paule Hamon for her help in operating the Ingenuity Pathway Analysis ${ }^{\mathrm{TM}}$ software. This work was supported by funds from MENRT and European $6^{\text {th }}$ Framework Program Grant Proteomage LSHM-CT518230. 


\section{REFERENCES}

Adnot S, Amsellem V, Boyer L, Marcos E, Saker M, Houssaini A, Kebe K, Dagouassat M, Lipskaia

L, Boczkowski J. Telomere Dysfunction and Cell Senescence in Chronic Lung Diseases: Therapeutic Potential. Pharmacol Ther. 2015; 153:125-134.

Ahmed EK, Rogowska-Wrzesinska A, Roepstorff P, Bulteau AL, and Friguet B. Protein modification and replicative senescence of WI-38 human embryonic fibroblasts. Aging Cell. 2010; 9:252-272.

Baker DJ, Wijshake T, Tchkonia T, LeBrasseur NK, Childs BG, van de Sluis B, Kirkland JL, van Deursen JM. Clearance of p16Ink4a-positive senescent cells delays ageing-associated disorders. Nature. 2011; 479:232-236.

Baraibar MA, Hyzewicz J, Rogowska-Wrzesinska A, Ladouce R, Roepstorff P, Mouly V, and Friguet B. Oxidative stress-induced proteome alterations target different cellular pathways in human myoblast. Free Radic Biol Med. 2011; 51:1522-1532.

Baraibar MA, and Friguet B. Changes of the proteasomal system during the ageing process. Prog Mol Biol Transl Sci. 2012; 109:249-275.

Baraibar MA, Liu L, Ahmed EK, and Friguet B. Protein oxidative damage at the crossroads of cellular senescence, ageing, and age-related diseases. Oxid Med Cell Longev. 2012; 2012:919832.

Baraibar MA, and Friguet B. Oxidative proteome modifications target specific cellular pathways during oxidative stress, cellular senescence and ageing. Exp Gerontol. 2013; 48:620-625.

Baraibar MA, Ladouce R, Friguet B. Proteomic quantification and identification of carbonylated proteins upon oxidative stress and during cellular aging. J Proteomics. 2013; 92:63-70. 
Baraibar MA, Hyzewicz J, Rogowska-Wrzesinska A, Bulteau AL, Prip-Buus C, Butler-Browne G, Friguet B. Impaired energy metabolism of senescent muscle satellite cells is associated with oxidative modifications of glycolytic enzymes. Aging (Albany NY). 2016; 8:3375-3389.

Benvenuti S, Cramer R, Quinn CC, Bruce J, Zvelebil M, Corless S, Bond J, Yang A, Hockfield S, Burlingame AL, Waterfield MD, and Jat PS. Differential proteome analysis of replicative senescence in rat embryo fibroblasts. Mol Cell Proteomics. 2002; 1:280-292.

Bernard D, Gosselin K, Monte D, Vercamer C, Bouali F, Pourtier A, Vandenbunder B, Abbadie C. Involvement of Rel/nuclear factor-kappaB transcription factors in keratinocyte senescence. Cancer Res. 2004; 64:472-481.

Bertrand-Vallery V1, Boilan E, Ninane N, Demazy C, Friguet B, Toussaint O, Poumay Y, DebacqChainiaux F. Repeated exposures to UVB induce differentiation rather than senescence of human keratinocytes lacking p16(INK-4A). Biogerontology. 2010; 11:167-181.

Boilan E, Winant V, Dumortier E, Piret JP, Bonfitto F, Osiewacz HD, Debacq-Chainiaux F, Toussaint O. Role of p38MAPK and oxidative stress in copper-induced senescence. Age. 2013; 35:2255-2271.

Bulteau AL, Petropoulos I, Friguet B. Age-related alterations of proteasome structure and function in aging epidermis. Exp Gerontol. 2000; 35:767-777.

Campisi J, and Robert L. Cell senescence: role in aging and age-related diseases. Interdiscip Top Gerontol. 2014; 39:45-61. 
Chondrogianni N, Stratford FL, Trougakos IP, Friguet B, Rivett AJ, Gonos ES. Central role of the proteasome in senescence and survival of human fibroblasts: induction of a senescence-like phenotype upon its inhibition and resistance to stress upon its activation. J Biol Chem. 2003; 278 :28026-28037.

Chondrogianni N, Petropoulos I, Grimm S, Georgila K, Catalgol B, Friguet B, Grune T, and Gonos ES. Protein damage, repair and proteolysis. Mol Asp Med. 2014; 35:1-71.

Cuervo AM, and Wong E. Chaperone-mediated autophagy: roles in disease and aging. Cell Res. 2014; 24:92-104

Cutler RG, Kelly J, Storie K, Pedersen WA, Tammara A, Hatanpaa K, Troncoso JC, and Mattson MP. Involvement of oxidative stress-induced abnormalities in ceramide and cholesterol metabolism in brain aging and Alzheimer's disease. Proc Natl Acad Sci U S A. 2004; 101:2070-2075.

Debacq-Chainiaux F, Borlon C, Pascal T, Royer V, Eliaers F, Ninane N, Carrard G, Friguet B, de Longueville F, Boffe S, Remacle J, Toussaint O. Repeated exposure of human skin fibroblasts to UVB at subcytotoxic level triggers premature senescence through the TGF- $\beta 1$ signaling pathway. J Cell Sci. 2005; 118:743-758.

DeHaven CD, Evans AM, Dai H, and Lawton KA. Organization of GC/MS and LC/MS metabolomics data into chemical libraries. J Cheminform. 2010; 2:9.

Dierick JF, Pascal T, Chainiaux F, Eliaers F, Remacle J, Larsen PM, Roepstorff P, Toussaint O. Transcriptome and proteome analysis in human senescent fibroblasts and fibroblasts undergoing premature senescence induced by repeated sublethal stresses. Ann N Y Acad Sci. 2000; 908:302-305. 
Dierick JF, Kalume DE, Wenders F, Salmon M, Dieu M, Raes M, Roepstorff P, and Toussaint O. Identification of 30 protein species involved in replicative senescence and stress-induced premature senescence. FEBS Lett. 2002; 531:499-504.

Dimri GP, Lee X, Basile G, Acosta M, Scott G, Roskelley C, Medrano EE, Linskens M, Rubelj I, Pereira-Smith O, Peacocke M, Campisi J. A biomarker that identifies senescent human cells in culture and in skin in vivo. Proc Natl Acad Sci U S A. 1995; 92:9363-9367.

Dumont P, Burton M, Chen QM, Gonos ES, Frippiat C, Mazarati JB, Eliaers F, Remacle J, Toussaint O. Induction of replicative senescence biomarkers by sublethal oxidative stresses in normal human fibroblast. Free Radic Biol Med. 2000; 28:361-373.

Friguet B. Oxidized protein degradation and repair in ageing and oxidative stress. FEBS Lett. 2006; 580:2910-2916.

Frippiat C, Chen QM, Zdanov S, Magalhaes JP, Remacle J, Toussaint O. Subcytotoxic H2O2 stress triggers a release of transforming growth factor-beta 1, which induces biomarkers of cellular senescence of human diploid fibroblasts. J Biol Chem. 2001; 276:2531-2537.

Grune T, Jung T, Merker K, Davies KJ. Decreased proteolysis caused by protein aggregates, inclusion bodies, plaques, lipofuscin, ceroid, and 'aggresomes' during oxidative stress, aging, and disease. Int J Biochem Cell Biol. 2004; 36:2519-2530.

Gurjala AN, Liu WR, Mogford JE, Piero SA, Procaccini BA, Mustoe TA. Age-dependent response of primary human dermal fibroblasts to oxidative stress: cell survival, pro-survival kinases, and entrance into cellular senescence. Wound Repair Regen. 2005; 13:565-575. 
Hutter E, Renner K, Pfister G, Stöckl P, Jansen-Dürr P, and Gnaiger E. Senescence-associated changes in respiration and oxidative phosphorylation in primary human fibroblasts. Biochem J. 2004; 380:919-928.

James EL, Lane JA, Michalek RD, Karoly ED, Parkinson EK. Replicatively senescent human fibroblasts reveal a distinct intracellular metabolic profile with alterations in NAD+ and nicotinamide metabolism. Sci Rep 2016; 6:38489.

Khotskaya YB, Holla VR, Farago AF, Mills Shaw KR, Meric-Bernstam F, Hong DS. Targeting TRK family proteins in cancer. Pharmacol Ther. 2017. pii: S0163-7258(17)30020-30027.

Laemmli UK. Cleavage of structural proteins during the assembly of the head of bacteriophage T4. Nature. 1970; 227:680-685.

Levine RL, and Stadtman ER. Oxidative modification of proteins during aging. Exp Gerontol. 2001; 36:1495-1502.

Love NR, Pollak N, Dölle C, Niere M, Chen Y, Oliveri P, Amaya E, Patel S, Ziegler M. NAD kinase controls animal NADP biosynthesis and is modulated via evolutionarily divergent calmodulindependent mechanisms. Proc Natl Acad Sci U S A. 2015; 112:1386-1391.

Maruyama J, Naguro I, Takeda K, Ichijo H. Stress-activated MAP kinase cascades in cellular senescence. Curr Med Chem. 2009;16:1229-35.

Møller IM, Rogowska-Wrzesinska A, Rao RS. Protein carbonylation and metal-catalyzed protein oxidation in a cellular perspective. J Proteomics. 2011; 74:2228-2242. 
Murata S, Chiba T, Tanaka K. CHIP: a quality-control E3 ligase collaborating with molecular chaperones. Int J Biochem Cell Biol. 2003; 35:572-578.

Nowotny K, Jung T, Grune T, Höhn A. Accumulation of modified proteins and aggregate formation in aging. Exp Gerontol. 2014; 57:122-31.

Nystrom T. Role of oxidative carbonylation in protein quality control and senescence. EMBO J. 2005; 24:1311-1317.

Petropoulos I, and Friguet B. Protein maintenance in aging and replicative senescence: a role for the peptide methionine sulfoxide reductases. Biochim Biophys Acta / Proteins and Proteomics, 2005; 1703:261-266.

Reitman ZJ, Jin G, Karoly ED, Spasojevic I, Yang J, Kinzler KW, He Y, Bigner DD, Vogelstein B, Yan $\mathrm{H}$. Profiling the effects of isocitrate dehydrogenase 1 and 2 mutations on the cellular metabolome. Proc Natl Acad Sci U S A. 2011; 108:3270-3275.

Rogowska-Wrzesinska A, Le Bihan MC, Thaysen-Andersen M, Roepstorff P. 2D gels still have a niche in proteomics. J Proteomics. 2013;88:4-13.

Rogowska-Wrzesinska A, Wojdyla K, Nedić O, Baron CP, Griffiths HR. Analysis of protein carbonylation--pitfalls and promise in commonly used methods. Free Radic Res. 2014; 48:1145-1162.

Salminen A, Kauppinen A, Kaarniranta K. Emerging role of NF- $\mathrm{BB}$ signaling in the induction of senescence-associated secretory phenotype (SASP). Cell Signal. 2012; 24:835-845.

Sisoula C, Gonos ES. CHIP E3 ligase regulates mammalian senescence by modulating the levels of oxidized proteins. Mech Ageing Dev. 2011; 132:269-272. 
Stadtman ER. Protein oxidation and aging. Free Radic Res. 2006; 40:1250-1258.

Tamarit J, de Hoogh A, Obis E, Alsina D, Cabiscol E, Ros J. Analysis of oxidative stress-induced protein carbonylation using fluorescent hydrazides. J Proteomics. 2012; 75:3778-3788.

Toussaint O, Dumont P, Dierick JF, Pascal T, Frippiat C, Chainiaux F, Sluse F, Eliaers F, Remacle J. Stress-induced premature senescence. Essence of life, evolution, stress, and aging. Ann N Y Acad Sci. 2000a; 908:85-98.

Toussaint O, Medrano EE, von Zglinicki T. Cellular and molecular mechanisms of stress-induced premature senescence (SIPS) of human diploid fibroblasts and melanocytes. Exp Gerontol. 2000b; $35: 927-45$

Toussaint O, Royer V, Salmon M, Remacle J. Stress-induced premature senescence and tissue ageing. Biochem Pharmacol. 2002a; 64:1007-1009.

Toussaint O, Remacle J, Dierick JF, Pascal T, Frippiat C, Zdanov S, Magalhaes JP, Royer V, Chainiaux F. From the Hayflick mosaic to the mosaics of ageing. Role of stress-induced premature senescence in human ageing. Int J Biochem Cell Biol. 2002b; 34:1415-1429. 
A

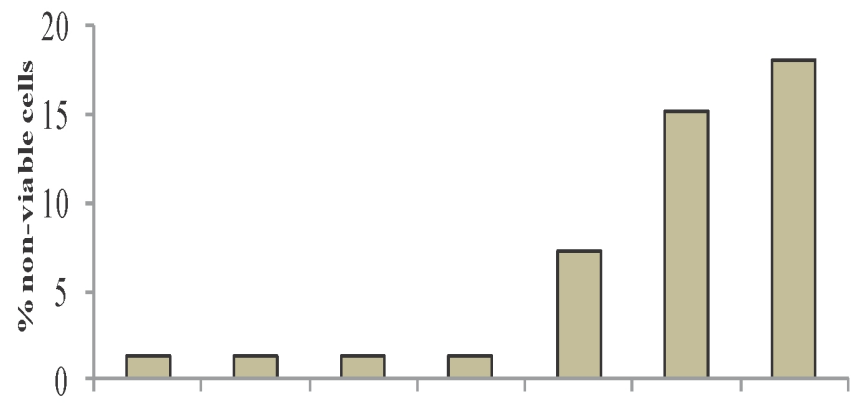

Control $\quad 300 \mu \mathrm{M} \quad 400 \mu \mathrm{M} \quad 500 \mu \mathrm{M} \quad 550 \mu \mathrm{M} \quad 600 \mu \mathrm{M} \quad 650 \mu \mathrm{M}$ H202 concentration

B Time

kDa Control Oh 2h 4h 7 h d1 d2 d4 d7 $d 9$ d15
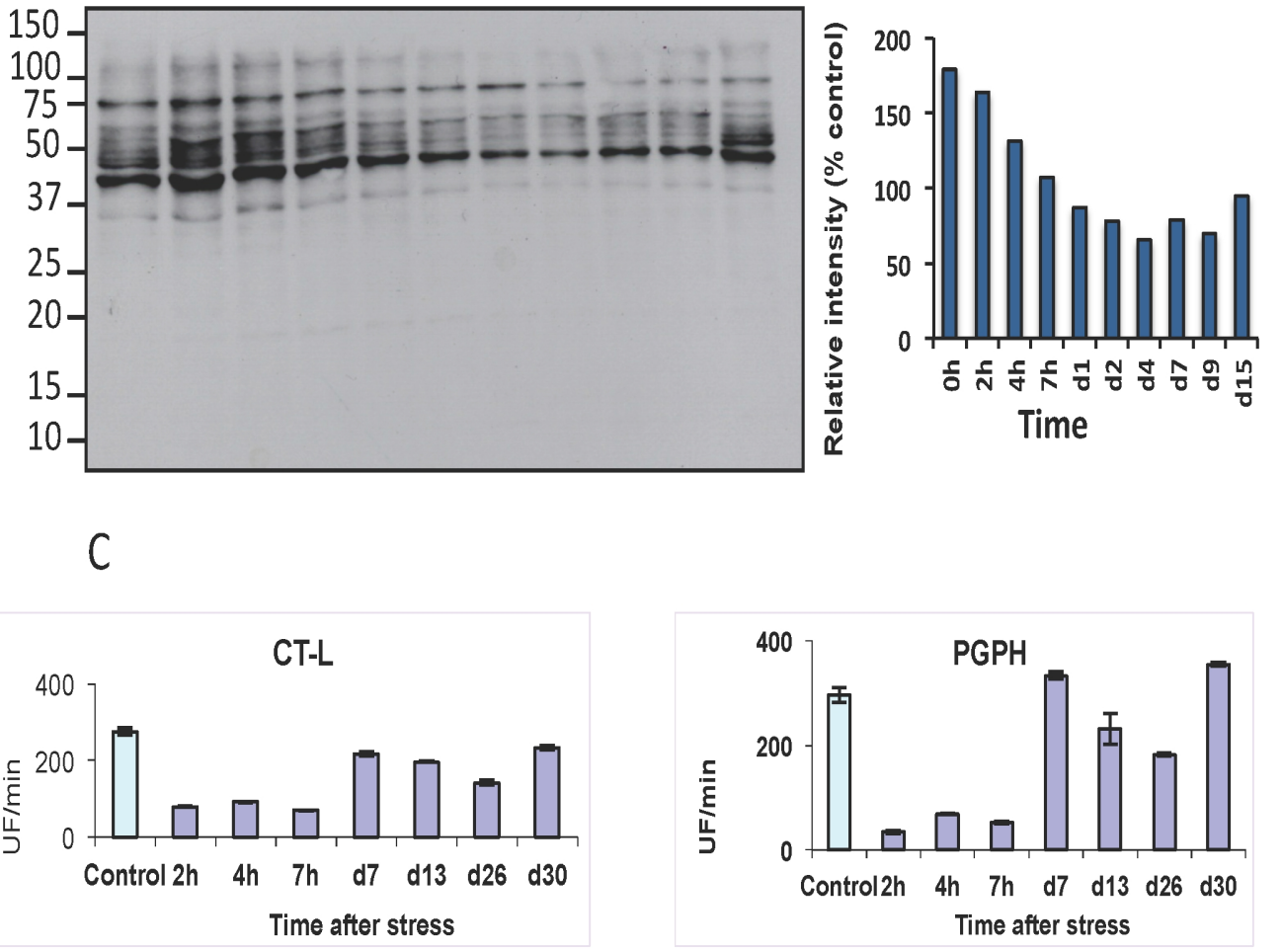

D

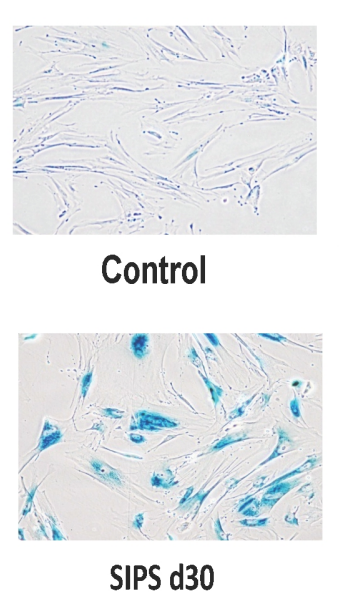

E

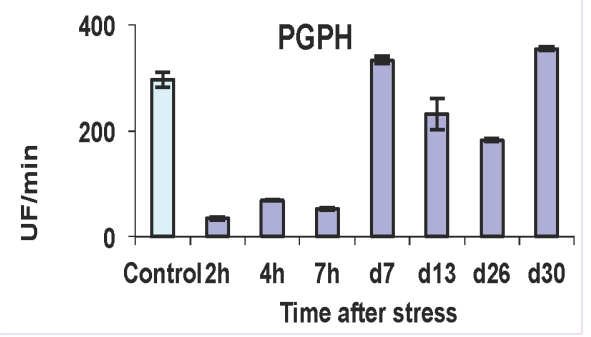

$\mathrm{X} 200$

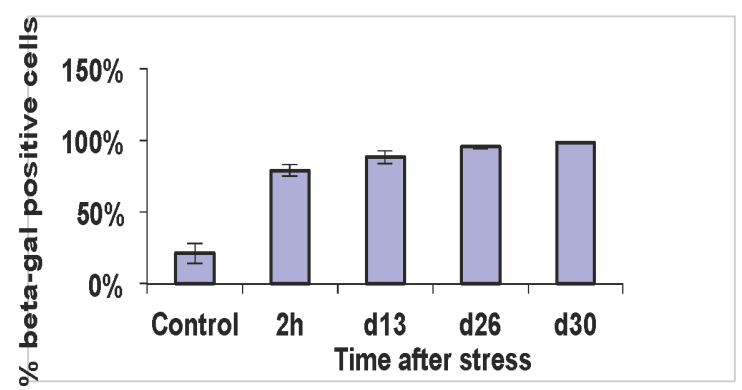



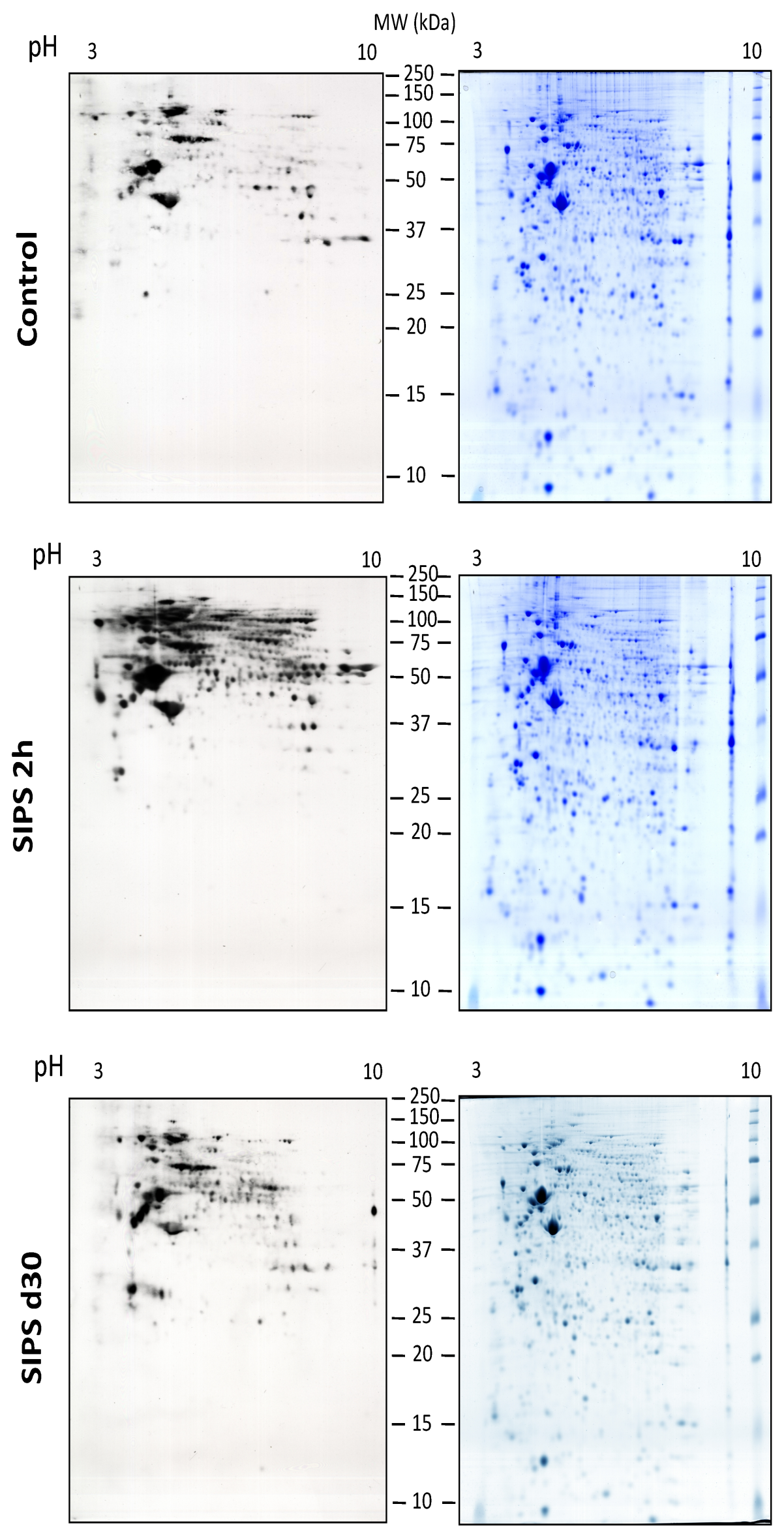
pH
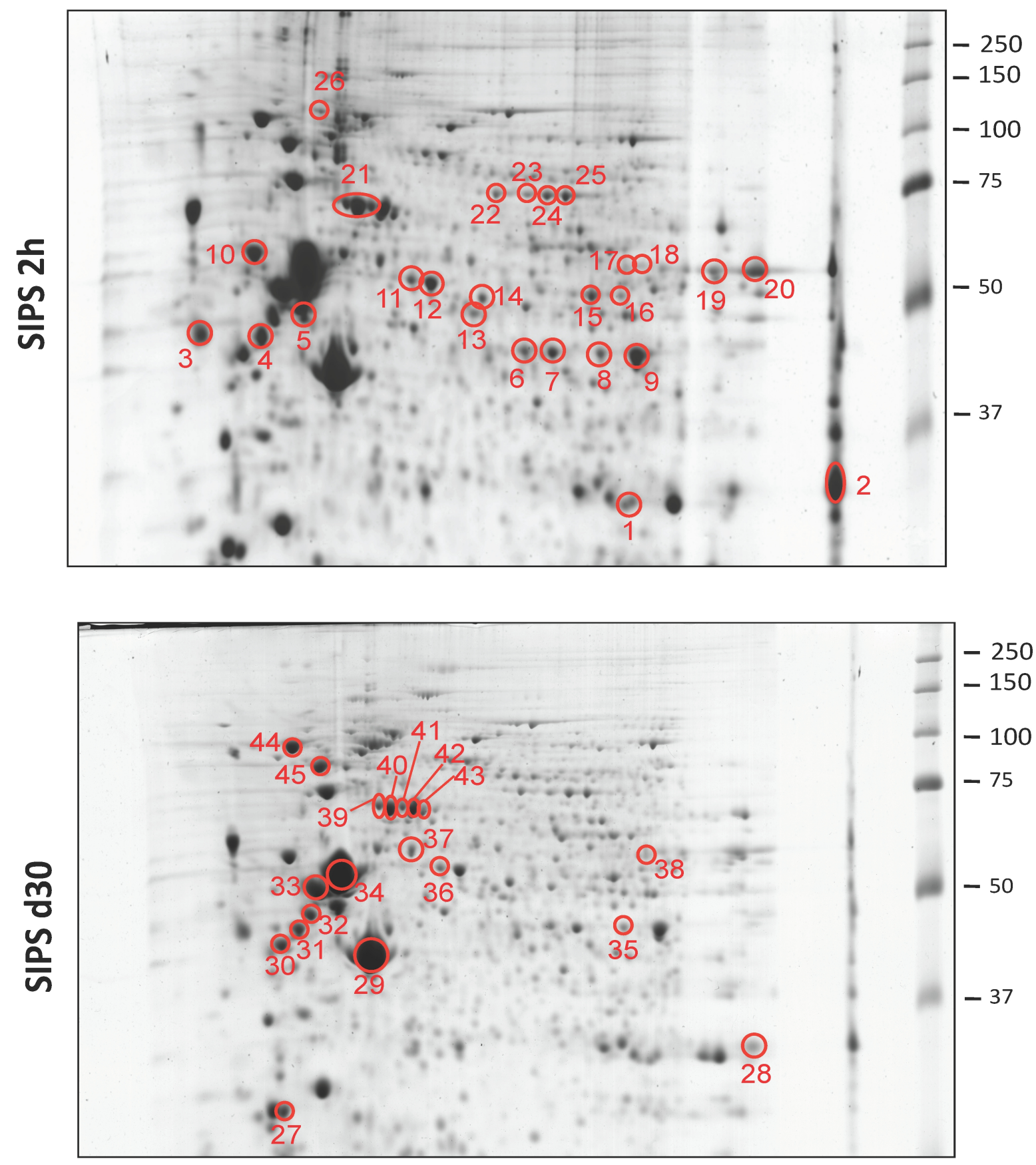


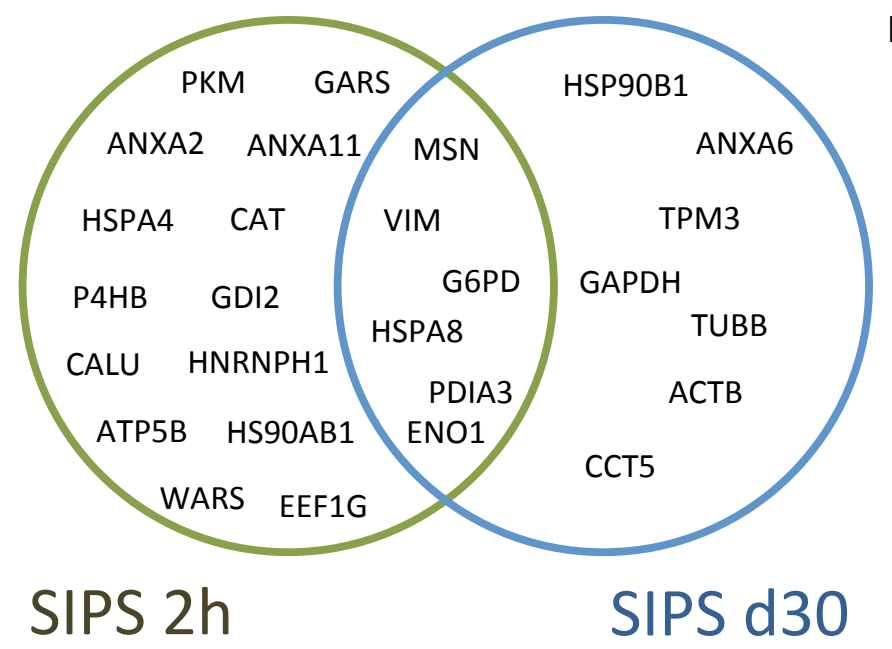

Isobar : ribulose 5-phosphate, xylulose 5-phosphate

C

D

Nicotinamide adenine dinucleotide phosphate

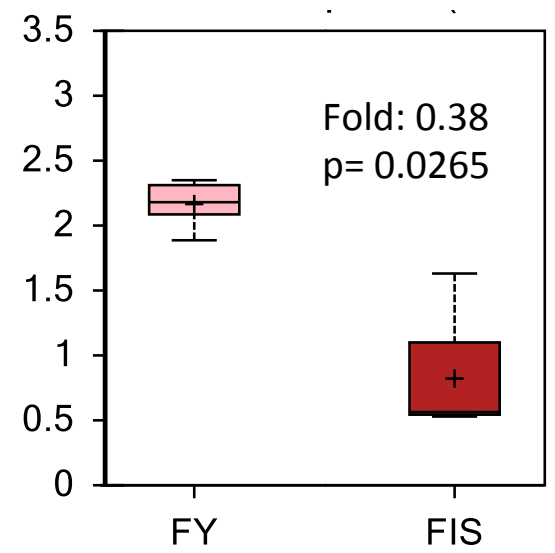

E

Cysteine-glutathione disulfide

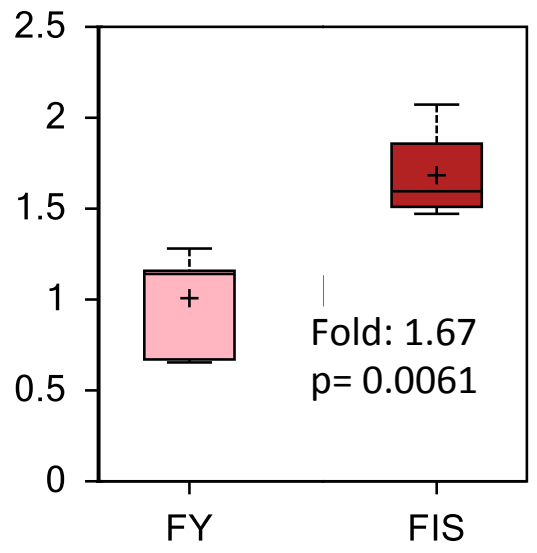

$\mathrm{F}$

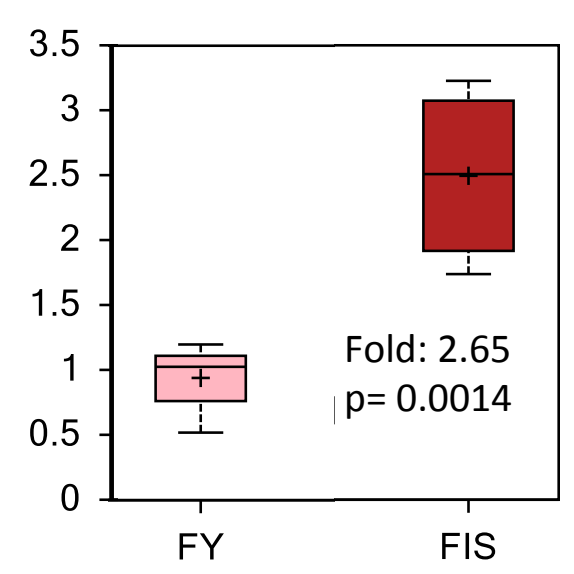

$F$

Methionine sulfoxide 


\section{A}

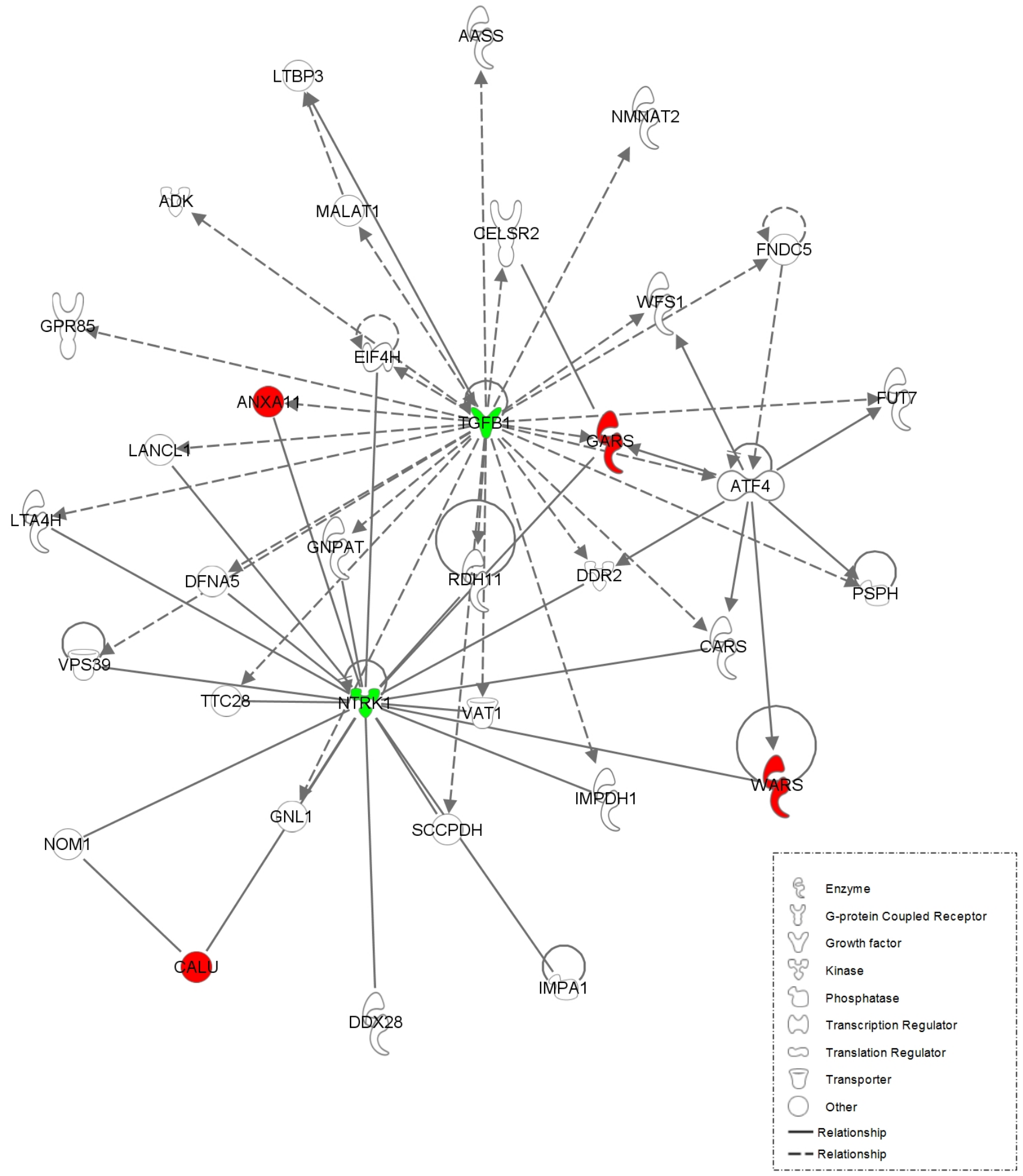


B

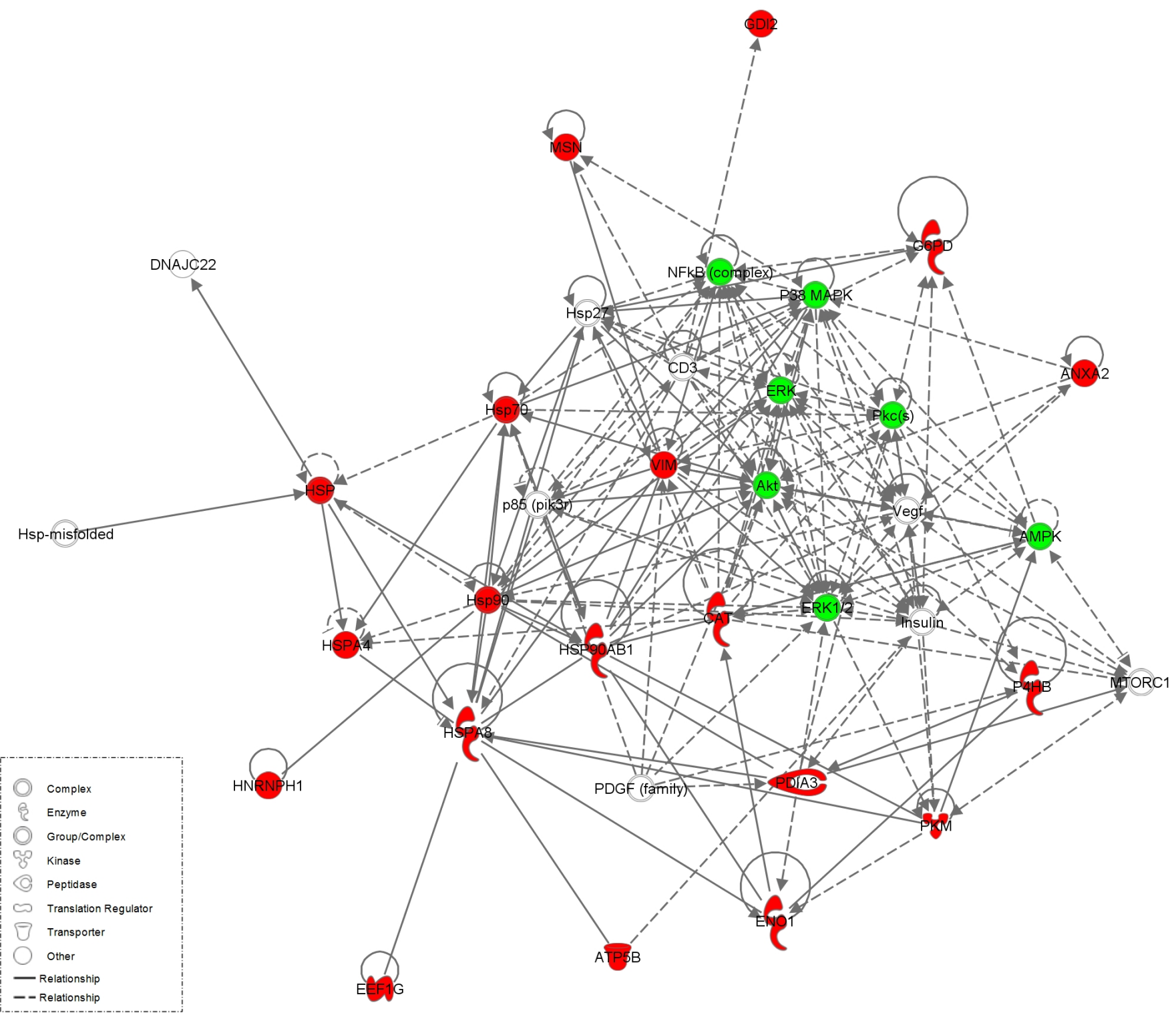




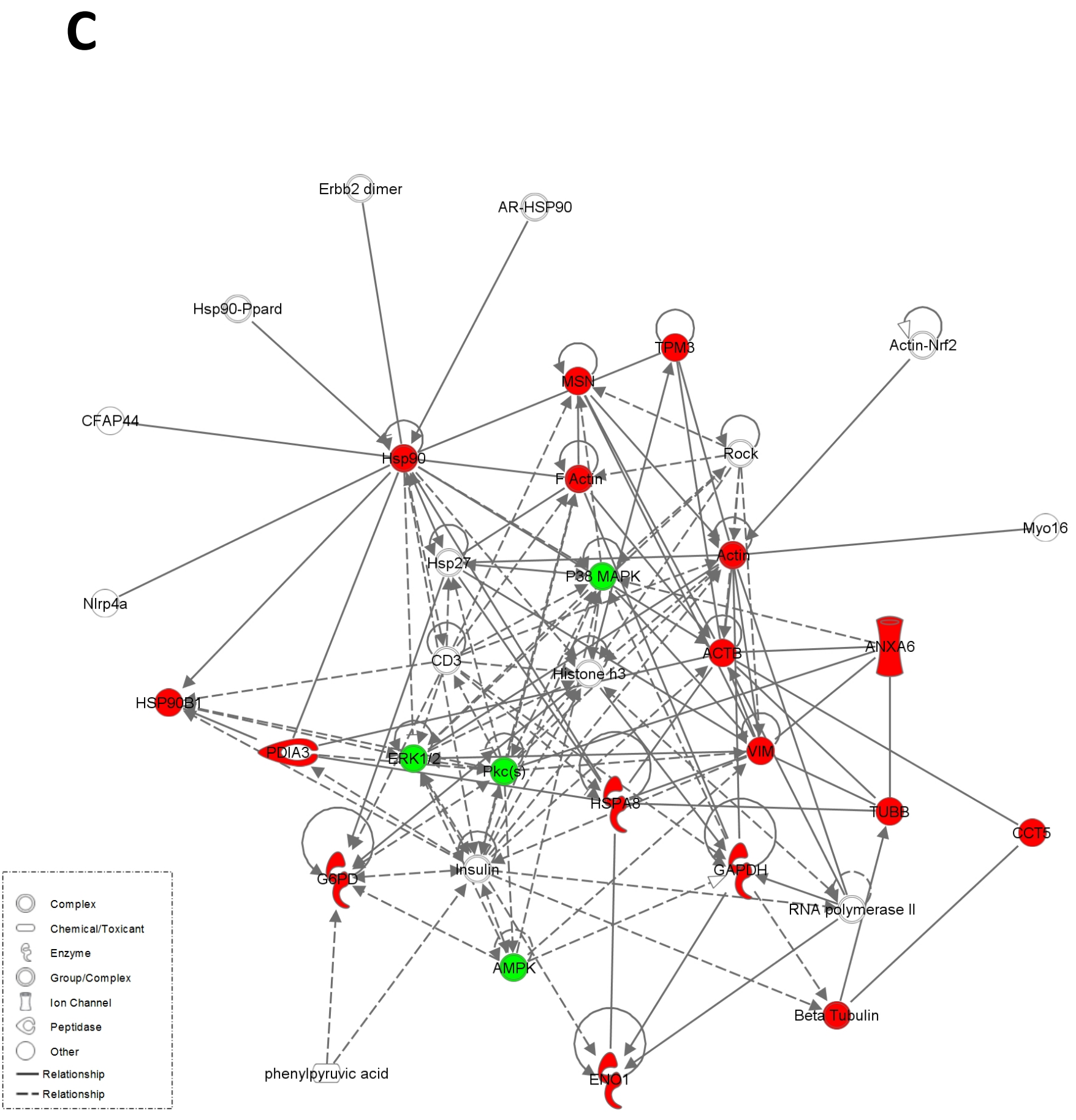


Table 1

\begin{tabular}{|c|c|c|c|c|c|c|c|c|}
\hline \multicolumn{9}{|c|}{ Carbonylated proteins in stress-induced premature senescent WI-38 fibroblasts (SIPS 2h) } \\
\hline 1 & Annexin A2 & ANXA2_HUMAN & ANXA2 & 38580 & 677 & 31 & $\begin{array}{l}\text { Membrane } \\
\text { scaffolding }\end{array}$ & 4.2 \\
\hline 2 & Vimentin & VIME_HUMAN & VIM & 53619 & 853 & 42 & Cytoskeletal & 3.4 \\
\hline 5 & $\begin{array}{l}\text { ATP synthase subunit beta, } \\
\text { mitochondrial }\end{array}$ & ATPB_HUMAN & ATP5B & 56525 & 798 & 56 & $\begin{array}{l}\text { Energy } \\
\text { metabolism }\end{array}$ & 1.7 \\
\hline 6 & $\begin{array}{l}\text { Rab GDP dissociation inhibitor } \\
\text { beta }\end{array}$ & GDIB_HUMAN & GDI2 & 50631 & 540 & 43 & $\begin{array}{l}\text { Signal } \\
\text { transduction }\end{array}$ & 3.1 \\
\hline 7 & Elongation factor 1-gamma & EF1G_HUMAN & EEF1G & 50087 & 497 & 26 & $\begin{array}{l}\text { Protein } \\
\text { biosynthesis }\end{array}$ & 4.7 \\
\hline 10 & Protein disulfide-isomerase A1 & PDIA1_HUMAN & PDIA1 & 57081 & 573 & 43 & Redox chaperone & 2.2 \\
\hline 11 & Protein disulfide-isomerase A3 & PDIA3_HUMAN & PDIA3 & 56747 & 703 & 44 & Redox chaperone & 3.5 \\
\hline 12 & Protein disulfide-isomerase A3 & PDIA3_HUMAN & PDIA3 & 56747 & 1170 & 38 & Redox chaperone & 4.8 \\
\hline 13 & $\begin{array}{l}\text { Heterogeneous nuclear } \\
\text { ribonucleoprotein } \mathrm{H}\end{array}$ & HNRH1_HUMAN & HNRNPH1 & 49198 & 676 & 43 & $\begin{array}{l}\text { RNA binding } \\
\text { protein }\end{array}$ & 1.6 \\
\hline 14 & $\begin{array}{l}\text { Tryptophanyl-tRNA } \\
\text { synthetase, cytoplasmic }\end{array}$ & SYWC_HUMAN & WARS & 53132 & 484 & 24 & $\begin{array}{l}\text { Protein } \\
\text { biosynthesis }\end{array}$ & 1.8 \\
\hline 15 & $\begin{array}{l}\text { Glucose-6-phosphate 1- } \\
\text { dehydrogenase }\end{array}$ & G6PD_HUMAN & G6PD & 59219 & 573 & 35 & $\begin{array}{l}\text { Energy } \\
\text { metabolism }\end{array}$ & 3.3 \\
\hline
\end{tabular}




\begin{tabular}{|l|l|l|l|l|l|l|l|l|}
\hline 16 & Annexin A11 & ANX11_HUMAN & ANXA11 & 54355 & 383 & 24 & $\begin{array}{l}\text { Membrane } \\
\text { scaffolding }\end{array}$ & $\begin{array}{l}4.6 \\
\text { Energy } \\
\text { metabolism }\end{array}$ \\
\hline 17 & $\begin{array}{l}\text { Glucose-6-phosphate 1- } \\
\text { dehydrogenase }\end{array}$ & G6PD_HUMAN & G6PD & 59219 & 573 & 35 & ROS scavenging & h \\
\hline 18 & Catalase & CATA_HUMAN & CAT & 59719 & 134 & 14 & $\begin{array}{l}5.4 \\
\text { Energy } \\
\text { m1/M2 }\end{array}$ \\
\hline 19 & $\begin{array}{l}\text { Pyruvate kinase isozymes } \\
\text { M1/M2 }\end{array}$ & KPYM_HUMAN & PKM & 57900 & 926 & 38 & $\begin{array}{l}\text { Energy } \\
\text { metabolism }\end{array}$ \\
\hline 20 & $\begin{array}{l}\text { Heat shock cognate 71 kDa } \\
\text { protein }\end{array}$ & HSP7C_HUMAN & HSPA8 & 70854 & 1190 & 34 & Chaperone & 2.7 \\
\hline 21 & $\begin{array}{l}\text { Glycyl-tRNA synthetase } \\
22\end{array}$ & SYG_HUMAN & GARS & 83113 & 491 & 24 & $\begin{array}{l}\text { Protein } \\
\text { biosynthesis }\end{array}$ \\
\hline 23 & $\begin{array}{l}\text { Heat shock protein HSP 90- } \\
\text { beta }\end{array}$ & HS90B_HUMAN & HSP90AB1 & 83212 & 978 & 23 & Chaperone & 2.3 \\
\hline 24 & Moesin & MOES_HUMAN & MSN & 67778 & 749 & 28 & Cytoskeletal & 2.2 \\
\hline 25 & Moesin & MOES_HUMAN & MSN & 67778 & 648 & 29 & Cytoskeletal & 2.8 \\
\hline 26 & Heat shock 70 kDa protein 4 & HSP74_HUMAN & HSPA4 & 94271 & 545 & 35 & Chaperone & 2.9 \\
\hline
\end{tabular}

Spots of interest were identified by MS as described in Material and Methods. Protein spot no (a) refer to numbered spots on Figure 3. For each spot, different parameters clarifying protein identification by MS are indicated [(accession number (b), Ingenuity Pathway Analysis symbol (c) mass (d), mascot score (e), \% sequence coverage (f)].

(g) RMI ratio represents the Relative Modification Index Ratio and (h) means that the modified protein was only detected in SIPS $2 \mathrm{~h}$ samples. 
Table 2

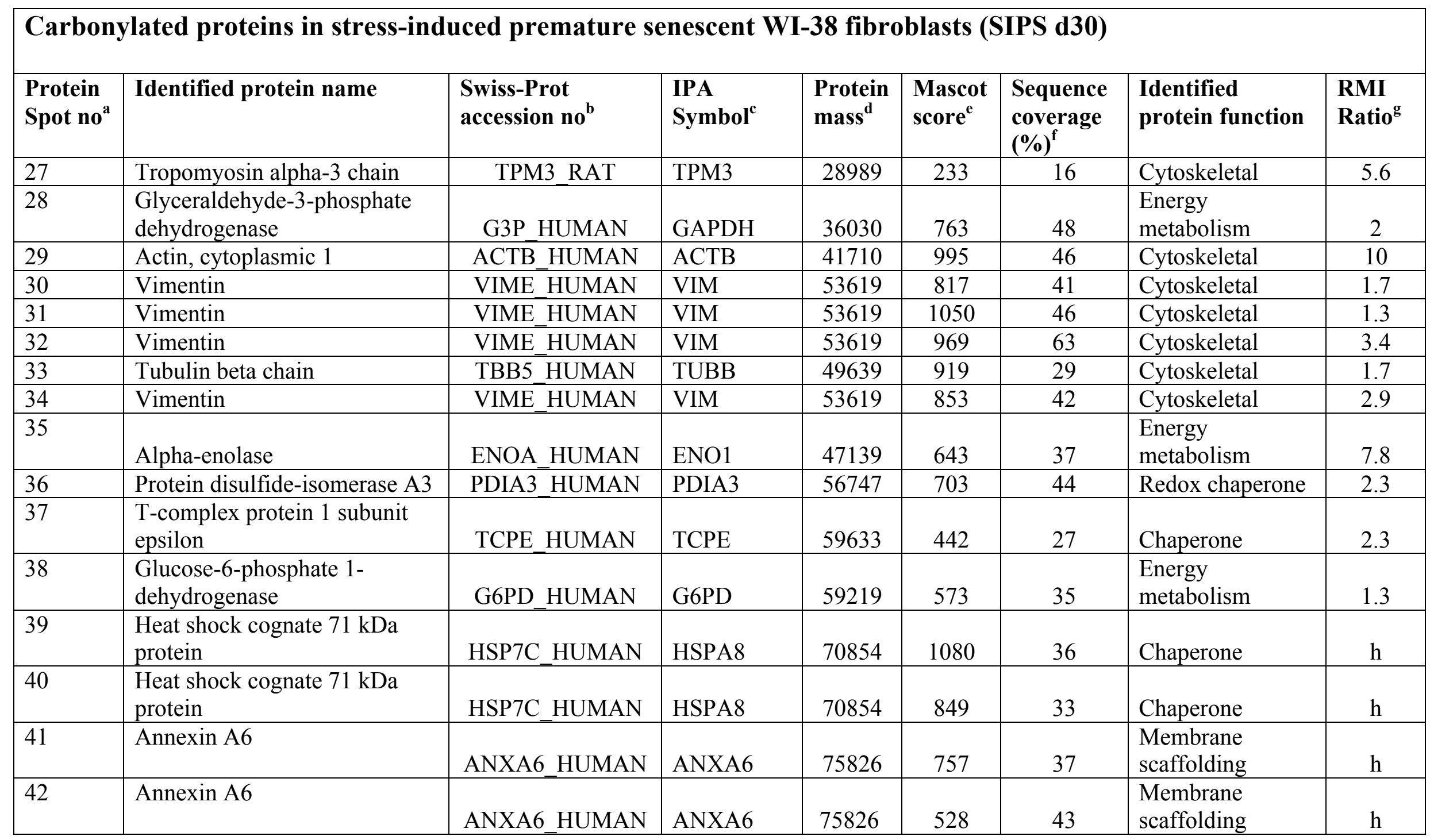




\begin{tabular}{|l|l|c|l|l|l|l|l|c|}
\hline 43 & Annexin A6 & ANXA6_HUMAN & ANXA6 & 75826 & 888 & 42 & $\begin{array}{l}\text { Membrane } \\
\text { scaffolding }\end{array}$ & \multicolumn{1}{c|}{ h } \\
\hline 44 & Endoplasmin & ENPL_HUMAN & HSP90B1 & 92411 & 454 & 38 & Chaperone & 4.7 \\
\hline 45 & Moesin & MOES_HUMAN & MSN & 67778 & 749 & 28 & Cytoskeletal & 1.8 \\
\hline
\end{tabular}

Spots of interest were identified by MS as described in Material and Methods. Protein spot no (a) refer to numbered spots on Figure 3. For each spot, different parameters clarifying protein identification by MS are indicated [(accession number (b), Ingenuity Pathway Analysis symbol (c) mass (d), mascot score (e), \% sequence coverage (f)].

(g) RMI ratio represents the Relative Modification Index Ratio and (h) means that the modified protein was only detected in SIPS d30 samples. 